\title{
Pengembangan Alat Ukur Quality of Life Urban Community
}

\author{
Yeni Anna Appulembang ${ }^{1}$ dan Fransisca Iriani R. Dewi ${ }^{2}$ \\ ${ }^{1}$ Fakultas Psikologi, UniversitasTarumanagara Jakarta \\ Email: yennia@fpsi.untar.ac.id \\ ${ }^{2}$ FakultasPsikologi, UniversitasTarumanagara Jakarta \\ Email: fransiscar@fpsi.untar.ac.id
}

\begin{abstract}
ABSTRAK
Kajian mengenai kualitas hidup sudah semakin berkembang dalam beberapa dekade terakhir. Kualitas hidup menurut WHO menekankan adanya persepsi dari individu mengenai posisi kehidupan.Kajian mengenai kualitas hidup sudah semakin berkembang dalam beberapa dekade terakhir. Ide awal pengukuran kualitas hidup untuk mengetahui sejauh mana sekelompok masyarakat memiliki standarisasi dalam kehidupan yang diukur dari aspek kualitas kehidupan mereka (Cummin \& Liitchers dalam Saputra \& Nurizzka, 2008). Tujuan penelitian ini adalah pengembangan alat ukur quality of life khususnya masyarakat perkotaan di Jakarta. Butir-butir pada alat ukur ini digunakan untuk mengukur kualitas hidup masyarakat diperkotaan. Metode penelitian yang digunakan adalah survei dengan jumlah responden sebanyak 586 subyek. Karakteristik subyek pada penelitian ini adalah dewasa yang berusia minimal 20 - 60 tahun, tinggal di Jakarta dan berjenis kelamin pria atau wanita. Alat ukur ini berlandaskan teori dari WHO maupun penemuan dari Alberta's Development Fund (RADF) yang dilakukan pada tahun 2009. Dengan menggunakan temuan Alberta's Development Fund ( RADF), penelitian ini menggunakan tujuh faktor yaitu: (1) Emotional Well-Being; (2) Interpersonal Relations; (3) Material Well-Being; (4) Personal Development; (5) Physical Well-Being; (6) Self-Determination; (7) Social Inclusion. Pada penelitian ini dilakukan beberapa pengujian diantaranya adalah pengujian face validity, content validity, internal consistency reliability. Pada pengujian reliabilitas, diperoleh nilai internal consistency reliability sebesar 0.923. Selain itu juga dilakukan uji perbedaan pada sosio demografis seperti usia, jenis kelamin, wilayah tinggal. Hasil uji perbedaan hanya menemukan adanya perbedaan quality of life berdasarkan usia.
\end{abstract}

Kata kunci: alat ukur quality of life, urban community.

\section{PENDAHULUAN}

Masyarakat perkotaan khususnya kota metropolitan seperti Jakarta terdiri dari keragaman sosial, ekonomi dan budaya, yang mencerminkan karakteristik masyarakat atau komunitas kawasan perkotaan (urban society atau urban community). Jakarta sebagai ibukota sebuah negara berkembang, tidak terlepas pembangunan yang berkelanjutan (sustainable development). Arti dari pembangunan yang berkelanjutan diberikan oleh Grizans (2009) "Sustainable development is a concept of growing popularity aimed at producing long-term global well-being through the wise use and management of economic and natural resources, and through respect for people and other living things. Sustainability is a concept describing mankind's ability to create a world for humans and non-humans that environmentally, socially, and economically provides for a current population's needs without damaging the ability of future generations to take care of themselves" (p. 13).

Pada intinya, pembangunan berkelanjutan akan menghasilkan kesejahteraan masyarakat melalui pengelolaan ekonomi dan sumber daya alam serta menghargai orang dan mahluk hidup lain. Ditambahkan oleh Grizans (2009), terdapat 4 pilar atau dimensi dalam pembangunan berkelanjutan yaitu: dimensi sosial, ekonomi, lingkungan dan insitusional. Ditambahkan Pacione (dalam Grizans) dimensi sosial diartikan bahwa pembangunan berkelanjutan telah mencapai keadilan sosial melalui alokasi sumberdaya yang adil, memberantas kemiskinan, dan menyediakan pelayanan sosial, seperti pendidikan, kesehatan dan kesejahteraan semua anggota masyarakat.

Dimensi sosial menjadi fokus penelitian ini yang diartikan sebagai kesejahteraan (well being) anggota masyarakat. Kesejahteraan dapat diukur melalui indeks kualitas hidup. Kajian mengenai 
kualitas hidup sudah semakin berkembang dalam beberapa dekade terakhir. Ide awal dari pengukuran kualitas hidup untuk mengetahui sejauh mana sekelompok masyarakat memiliki standarisasi dalam kehidupan yang diukur dari aspek kualitas kehidupan mereka(Cummin \& Liitchers dalam Saputra \& Nurizzka, 2008). Liu (dalam Nofitri, 2009) mengindikasikan bahwa kualitas hidup merupakan suatu konsep yang bersifat subjektif.Definisi kualitas hidup menurut WHO menekankan adanya persepsi dari individu mengenai posisi kehidupan individu saat ini dan persepsi individu tersebut dapat dipengaruhi oleh budaya dan sistem nilai dimana individu tinggal.

Quality of life lebih didasarkan pada apa yang diinginkan oleh individu dapat tercapai. Individu akan memilih kualitas hidup mereka sehingga sesuai dengan apa yang dicari dan diinginkan. Quality of life merupakan pengalaman individu itu sendiri. Jika individu memiliki pengalaman hidup yang baik dan sesuai dengan yang diharapkan maka diasumsikan bahwa hidup mereka akan memperoleh kesenangan, kedamaian, dan kepuasaan hidup (Diener \& Suh, 1997).

Rural Albertas's Development Fund (RADF) melakukan survei sekitar bulan mengenai quality of life, kemampuan suatu komunitas, pelayanan kesehatan dan kesempatan pendidikan pelatihan. Survei ini menggunakan HRMC Quality of life dan Personal Well Being index untuk mengetahui kualitas kehidupan yang didasarkan pada pengalaman individuitu sendiri. Personal Wellbeing Index diciptakan dari Comprehensive Quality of Life Scale (ComQol), terdiri dari pengukuran kualitas hidup baik secara obyektif maupun subyektif (Cummins, McCabe, Romeo, \& Gullone, dalam International Wellbeing Group, 2013).

Pendekatan yang digunakan dalam mengukur quality of life dalam penelitian ini adalah dengan menggunakan Alberta yang mengukur 1) Emotional Well-Being terdiri atas tiga indikator yaitu contentment, self concept (body image, ideal self, social self); (2) Interpersonal Relations terdiri atas tiga indikator yaitu relationship, support, trust; (3) Material Well-Being terdiri atas tiga indikator yaitu income adequacy, housing, disposable income; (4) Personal Development terdiri atas tiga indikator yaitu opportunity to grow (opportunity for an individual to acquire skills), personal competence, enjoyment of daily activities; (5) Physical Well-Being: health and health care, lifestyle choices (satisfaction with one's food choices), leisure; (6) Self-Determination terdiriatastigaindikatoryaituautonomy/ personal control (the individual's ability to control his or her own life), choices ( freedom to make his or her own choices), freedom to express views dan ; (7) Social Inclusion terdiri atas 3 indikator yaitu: community integration, community participation (able to participate in one's community and other social activities if so desired), support networks.

Penelitan ini dilakukan di Daerah Khusus Ibukota Jakarta atau yang biasa dikenal dengan DKI Jakarta sebagai ibukota negara Indonesia yang memiliki luas sekitar 661,52 km² dengan jumlah penduduk sekitar 9.991.788 jiwa ("Statistik Jumlah Penduduk", 2014). Setiap tahun jumlah penduduk Jakarta terus bertambah. Salah satu penyebabnya adalah Jakarta merupakan pusat pemerintahan dan perekonomian. Sebagai sebuah pusat perekonomian, Jakarta merupakan primadona bagi setiap orang yang menginginkan kehidupan yang lebih baik.

Sejauh yang diketahui penulis, belum cukup banyak alat ukur Quality of life dalam bahasa Indonesia khususnya untuk masyarakat perkotaan. Alat ukur dari WHO bersifat universal, sangat umum, sementara penulis menambahkan Alberta's Development Fund yang lebih sesuai untuk masyarakat perkotaan. Dengan demikian, perlu dilakukan penelitian khususnya dalam mengembangkan alat ukur mengenai kualitas hidup (Quality of life) masyarakat perkotaan yang 
diukur dari tujuh dimensi dari Alberta's Development Fund sehingga dapat memberikan gambaran mengenai kualitas hidup masyarakat yang hidup di perkotaan (urban community ).

\section{METODE PENELITIAN}

Penelitian ini menggunakan metode kuantitatif berupa pengembangan alat ukur. Alat ukur yang dikembangkan adalah quality of life berdasarkan Rural Alberta's Development Fund (RADF) dibuat pada tahun 2009. Teknik pengambilan sampling yang digunakan adalah convenience sampling. Responden dalam penelitian ini adalah masyarakat yang tinggal di Jakarta, usia dewasa, jenis kelamin pria dan wanita. Pengambilan data dilakukan dengan cara membagikan langsung dan melalui google drive. Jumlah responden dalam penelitian ini sebanyak 586 orang. Dalam penelitian ini, peneliti berfokus pada lima (5) wilayah di Jakarta yaitu: Jakarta Barat, Jakarta Utara, Jakarta Pusat, Jakarta Timur dan Jakarta Selatan. Penelitian ini menggunakan temuan Rural Alberta's Development Fund (RADF) yang dibuat pada tahun 2009 sebagai dasar untuk pengembangan alat ukur dengan memperhatikan 7 faktor, dari 8 (delapan) faktor yang telah disusun oleh Rural Alberta's Development Fund (RADF) yaitu: (1) Emotional Well-Being "saya merasa puas dengan hidup saya"; (2) Interpersonal Relations. Salah satu contoh butir pada dimensi ini adalah "meskipun saya tinggal di Jakarta namun saya selalu percaya dengan orang yang baru saya kenal"; (3) Material Well-Being. Salah satu contoh butir pada dimensi ini adalah "saya merasa nyaman dengan kondisi rumah tempat saya tinggal saat ini"; (4) Personal Development. Salah satu contoh butir pada dimensi ini adalah "kemampuan yang saya miliki memudahkan saya untuk mendapatkan pekerjaan"; (5) Physical Well-Being. Salah satu contoh butir pada dimensi ini adalah "saya jarang berbelanja di mall"; (6) Self-Determination. Salah satu contoh butir pada dimensi ini adalah "dengan mudah saya dapat mengungkapkan pendapat/ pemikiran saya dan ; (7) Social Inclusion. Salah satu contoh butir pada dimensi ini adalah "saya aktif dalam komunitas di lingkungan tempatsayatinggal".

\section{HASIL DAN PEMBAHASAN}

Dalam menyusun alat ukur quality of life, peneliti melakukan hal, yaitu: (1) face validity, (2) content validity study, (3)pengumpulan data, (4) pengolahan data, (5) uji test-retest reliability; (6) analisis.

Pada penelitian ini dilakukan uji validitas berupa face validation study. Pada pengujian ini, peneliti memberikan kuesioner kepada calon responden untuk mengerjakan kuesioner tersebut dengan tujuan untuk memeriksa apakah calon responden mengerti isi, kalimat pada butir quality of life. Dalam pelaksanaan pengujian content validity, peneliti membuat meminta ijin kepada pakar untuk melakukan review mengenai butir pada quality of life dan mengenai proses dalam pengembangan alat ukur. Setelah dilakukan pengumpulan data, maka peneliti melakukan pengolahan data. Dalam pengembangan alat ukur quality of life, peneliti membuat butir dengan berlandaskan teori Kualitas hidup baik dari WHO maupun temuan Alberta's Development Fund (RADF) yang dilakukan pada tahun 2006. Kuesioner ini dibuat dengan menggunakan empat skala ( 1 = sangat tidak sesuai; 2 = tidak sesuai; 3 = sesuai; 4 = sangat sesuai). Setelah dilakukan pengujian reliabilitas, maka dilakukan analisis butir untuk memeriksa butir-butir tersebut valid. Butir dikatakan baik jika memiliki nilai $r$ lebih besar atau sama dengan 0.2. Pada penelitian ini, internal consistency reliability pada butir-butir quality of life sebesar 0.923. Langkah kelima adalah membuat analisis data, pada bagian ini peneliti membuat gambaran umum mengenai data responden, melakukan analisis data yang dikaitkan dengan quality of life seperti pada wilayah tempat tinggal, usia, dan jenis kelamin. Berdasarkan analisis Kolmogorov-Smirnov Test, menunjukkan data terdistribusi tidak normal $(0.000<0.05$ sehingga analisis menggunakan non parametric statistic. Dalam melakukan uji perbedaan, peneliti menggunakan nonparametrik 
karena data berada pada distribusi tidak normal $(0,000<0,05)$. Pertama, uji perbedaan dari variabel quality of life ditinjau dari jenis kelamin. Dengan menggunakan Analisis Mann Whitney $U$ sebesar 9350,00 dengan nilai $p$ sebesar, $795>0.05$. maka dapat disimpulkan bahwa tidak terdapat perbedaan antara quality of life pada pria dan wanita.

Kedua, uji perbedaan variabel quality of life ditinjau dari wilayah tempat tinggal. Dengan menggunakan analisis Kruskal Wallis dengan nilai koefisien Chi Square sebesar 1,972 dengan nilai $p$ sebesar $0,741>0.05$. Hal ini menunjukkan bahwa tidak terdapat perbedaan quality of life berdasarkan wilayah tempat tinggal di lima (5) wilayah jakarta. Ketiga, uji perbedaan variabel quality of life tinjau dari usia. Dengan menggunakan analisis Kruskal Wallis dengan nilai koefisien Chi Square sebesar 8,437 dengan nilai $p$ sebesar 0,07>0.05. Hal ini menunjukkan bahwa tidak terdapat perbedaan quality of life berdasarkan usia responden. Berdasarkan hasil analisis dilakukan uji korelasi dengan menggunakan Spearmanrank dan diperoleh hasil koefisien correlation sebesar 0,099 dan $p<0.05(0.017<0.05)$. Hal ini menunjukkan bahwa terdapat hubungan antara usia dengan quality of life.

\section{Pembahasan}

Penelitian ini ditujukan untuk mengembangkan suatu tes atau alat ukur yang dapat mengukur tingkat kualitas hidup (Quality of Life) pada dewasa yang tinggal di perkotaan khususnya di lima (5) wilayah di Jakarta dengan menggunakan konsep teori dari WHO dan Rural Alberta's Development Fund (RADF). World Health Organization (WHO) mendefinisikan quality of life atau kualitas hidup sebagai persepsi individu terhadap posisinya dalam kehidupan dalam konteks budaya dan sistem nilai dimana individu tinggal dan dalam hubungannya dengan tujuan, harapan, standar, dan hal lain yang menjadi perhatian individu (dikutip dalam Butler \& Ciarrochi, 2007). Kualitas hidup ini meliputi aspek fisik, mental, spiritual, dan sosial dan masing-masing aspek berkontribusi pada sense of well-being seseorang (Lopez \& Snyder, 2009). Berdasarkan pengertian WHO, Lopez, dan Snyder, kualitas hidup berkaitan dengan persepsi dan ekspektasi seseorang, jika seandainya ekspektasi tidak sesuai dengan perspesi maka well-being seseorang dapat terpengaruh.

Pada penelitian ini dilakukan analisis butir. Butir dikatakan baik jika memiliki nilai $r$ lebih besar atau sama dengan 0.2. Butir yang baik akan dipertahankan sedangkan butir yang tidak baik akan dihapuskan, sehingga tidak menjadi bagian dari alat ukur kualitas hidup masyarakat kota. Adapun terdapat 33 butir yang harus dibuang. Setelah butir dibuang maka diperoleh nilai internal consistency reliability sebesar 0.923, dapat dikatakan sangat baik internal consistency-nya. Dengan kata lain, bahwa butir-butir pada alat ukur quality of life saling interkorelasi. Konsistensi serta hasil koefisien pada internal consistency reliability didasarkan pada homogenitas butir-butirnya. Koefisien yang tinggi maka butir-butirnya akan saling berkorelasi dengan baik. Alat ukur ini juga sudah dilakukan uji content validity dan face validity untuk memeriksa butir apakah sudah mengukur yang akan diukur yaitu quality of life.

Temuan dalam penelitian menunjukan tidak terdapat perbedaan antara quality of life pada pria dan wanita, demikian pula tidak terdapat perbedaan usia. Temuan tersebut mendukung penelitian sebelumnya (Slavuj, 2011).

\section{KESIMPULAN}

Berdasarkan analisis data diperoleh tiga (3) hal yaitu (1) Uji reliabilitas (internal consistency reliability); (2) Uji Validitas yaitu content validity dan face validity; (3) analisis sosio demografi. 
Berikut ini akan dijelaskan lebih rinci. Pertama, berdasarkan hasil uji reliabilitas (internal consistency reliability) maka diperoleh hasil bahwa alat ukur ini memiliki nilai reliabilitas sebesar 0.923 . Kedua dilakukan pengujian validitas yaitu content validity kepada pakar untuk memeriksa apakah butir sudah mengukur dengan apa yang akan diukur. Pada penelitian ini dilakukan uji validitas berupa face validation study. Pada pengujian ini, peneliti memberikan kuesioner kepada calon responden untuk mengerjakan kuesioner tersebut dengan tujuan untuk memeriksa apakah calon responden mengerti isi, kalimat pada butir quality of life. Berdasarkan hasil pengujian diperoleh bahwa instruksi mudah untuk dipahami dan tata cara pengisian tidak rumit.

Ketiga, dilakukan uji perbedaan pada variabel quality of life ditinjau dari wilayah tempat tinggal, usia dan jenis kelamin. Pertama, uji perbedaan dari variabel quality of life ditinjau dari jenis kelamin. Dengan menggunakan Analisis Mann - Whitney $U$ sebesar 9350,00 dengan nilai $p$ sebesar, $795>0.05$. maka dapat disimpulkan bahwa tidak terdapat perbedaan antara quality of life pada pria dan wanita. Kedua, uji perbedaan variabel quality of life ditinjau dari wilayah tempat tinggal. Dengan menggunakan analisis Kruskal Wallis dengan nilai koefisien Chi Square sebesar 1,972 dengan nilai $p$ sebesar 0,741 >0.05. Hal ini menunjukkan bahwa tidak terdapat perbedaan quality of life berdasarkan wilayah tempat tinggal di lima (5) wilayah jakarta. Ketiga, uji perbedaan variabel quality of life tinjau dari usia. Dengan menggunakan analisis Kruskal Wallis dengan nilai koefisien Chi Square sebesar 8,437 dengan nilai $p$ sebesar 0,07>0.05. Hal ini menunjukkan bahwa tidak terdapat perbedaan quality of life berdasarkan usia responden. Berdasarkan hasil analisis dilakukan uji korelasi dengan menggunakan Speramanrank dan diperoleh hasil koefisien correlation sebesar 0,099 dan $p<0.05(0.017<0.05)$. Hal ini menunjukkan bahwa terdapat hubungan antara usia dengan quality of life.

\section{Saran}

Keterbatasan yang dihadapi dalam melakukan penelitian ini adalah pengumpulan data. Peneliti sulit untuk membuat kesetaraan atau pemerataan jumlah responden dari lima wilayah di Jakarta. Untuk itu, penelitian selanjutnya peneliti menyarankan melakukan teknik pengambilan sampel dengan teknik sampling kuota sehingga dapat menggambarkan representasi atau keterwakilan subyek, hal ini akan dapat menggambarkan kondisi yang sesungguhnya. Selain itu, perlu dilakukan studi lanjutan untuk menguji lebih mendalam mengenai informasi psikometrika seperti studi validitas dan reliabilitas.

\section{Ucapan Terima Kasih (Acknowledgement)}

Para peneliti mengucapkan terima kasih kepada Direktorat Penelitian dan Pengabdian Kepada Masyarakat (DPPM) Universitas Tarumanagara Jakarta, sehingga kegiatan penelitian ini dapat dilaksanakan dengan baik.

\section{REFERENSI}

Butler, J., \& Ciarrochi, J. (2007). Psychological acceptance and quality of life in the elderly. Quallity of Life Res. 16, 607-615.

Diener E \& Suh, E. (1997) Measuring quality of life: Economic, social, and subjective indicators. Social Indicators Research 40. 189-216.

Grizans, J (2009) Urban Issues and Solutions in the Context of Sustainable Development A review of the literature. Department of Environmental and Business Economics University of Southern Denmark.

International Wellbeing Group (2013). Personal Wellbeing Index: 5th Edition. Melbourne: Australian Centre on Quality of Life, Deakin University. 
Lopez, S.J., \& Snyder, C.R. (2009). Oxford handbook of positive psychology. New York: Oxford University Press.

Nofitri, N.F.M (2009) Gambaran kualitas hidup penduduk dewasa pada lima wilayah di Jakarta. Skripsi.

Saputra, W\& Nurizzka, R, H. (2008) Analisis kualitas hidup masyarakat di Sumatera Barat: Menggunakan metode Z- skor dengan data susenas 2008. Department Kesehatan Masyarakat Pasca Sarjana FKM - UI.

Proyeksi penduduk 2000-2025. (2014). Diunduh dari: http://www.datastatistik-indonesia.com/proyeksi/index.php?option=com_content\&task=vie w\&id=923\&Itemid=939\&lang=ide.

Rural Alberta Development Fund (2009) Quality of life and community capacity population survey: Baseline results: Howard Research and Management Consulting Inc. Retrieved from: www.radf.ca/uploads/qualityoflifesurvey-75714.pdf

Slavuj, L. (2011), Urban quality of life - a case study: The city of rijeka . Hrvatski Geografski Glasnik 73(1) 99 - 110.

WHO (1997) WHOQOL: Measuring quality of life.Programme On Mental HealthDivision Of Mental Health And Prevention Of Substance Abuse World Health. 